\title{
Urdimento
}

Revista de Estudos em Artes Cênicas

E-ISSN: 2358.6958

\section{O Teatro documentário e o Nordeste: documentos no processo de criação}

Entrevista com Quitéria Kelly concedida à Cleilson Queiroz Lopes

\section{Para citar este artigo:}

KELLY, Quitéria. O Teatro documentário e o Nordeste: documentos no processo de criação. Entrevista concedida à Cleison Queiroz Lopes. Urdimento, Florianópolis, v. 2, n. 38, ago./set. 2020.

DOI: http:/dx.doi.org/10.5965/14145731023820200047 
O Teatro documentário e o Nordeste: documentos no processo de criação

Quitéria Kelly entrevista concedida à Cleilson Queiroz Lopes

\title{
Resumo
}

Entrevista concedida via Skype pela atriz e diretora Quitéria Kelly do Grupo Carmin, na data 27 de janeiro de 2019, sobre os espetáculos Jacye A Invenção do Nordeste. A entrevista surgiu do meu interesse sobre Teatro documentário, e aborda duas peças de estética de Teatro Documentário do Grupo Carmin.

Palavras-chave: Teatro documentário. Teatro brasileiro. Grupos teatrais.

Documentary Theater and the northeast: documents in the creation process

\begin{abstract}
Interview via Skype by the actress and director Quiteria Kelly of the Carmin Group, on January 27, 2019, about the shows Jacy and A Invenção do Nordeste. The interview arose from my interest in documentary theater, and addresses two pieces of aesthetics from the Carmin Group Documentary Theater.
\end{abstract}

Keywords: Documentary theater. Brazilian theater. Theater groups.

${ }^{1}$ Pesquisador, professor, ator, dramaturgo e integrante da Companhia de Teatro Ortaet/Ceará. Doutorando em teatro no Programa de Pós-graduação em Teatro (PPGT), do Centro de Artes/UDESC.

cleilson-lopes@hotmail.com 
Figura 1 - Quitéria Kelly²

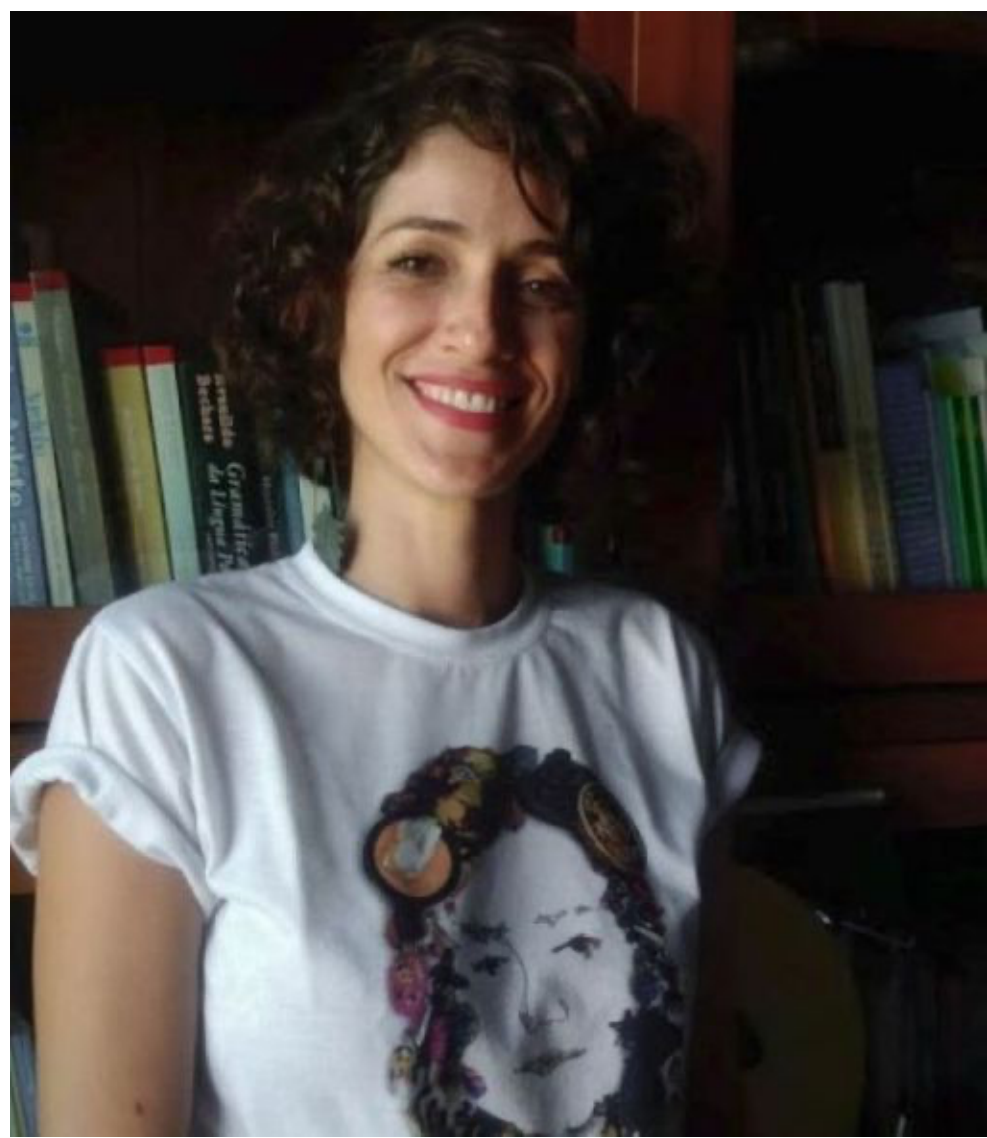

Atriz e diretora do coletivo teatral Carmin, graduada em teatro pela Universidade Federal do Rio Grande do Norte (UFRN), Quitéria Kelly dirige o espetáculo $A$ Invenção do Nordeste, montagem comemorativa dos 10 anos da companhia potiguar. Ao som de bandas do Rio Grande do Norte e de canções de Luiz Gonzaga e Tom Zé, ela fala sobre a peça, concebida a partir da tese de doutorado do prof. Durval Muniz de Albuquerque (UFRN), que busca desconstruir a imagem estereotipada do Nordeste e do nordestino, vistos quase sempre fora do impacto das grandes transformações sociais.

O Grupo Teatro Carmin foi criado em janeiro de 2007, em Natal (RN), com o desejo de pesquisar temas urbanos que pudessem ser retratados de forma cômica. A busca pelo riso não era gratuita e deveria proporcionar abertura para

${ }^{2}$ Fonte: https://observatoriodatv.uol.com.br/noticias/2019/04/atrizes-de-malhacao-abandonam-carroinvadido-por-agua-e-buscam-refugio-em-onibus-foi-desesperador. 
reflexão ou, como quis Georges Bataille, para uma “atitude filosófica”. O espetáculo inaugural do grupo foi Pobres de Marré, que trata sobre a exclusão social urbana no Nordeste brasileiro. Depois encenam - O Auto do Menino Deus (2009). Olha a Água (2010. Em 2011 se voltam para o universo infantil e encenam - Castelo de Lençóis. Em 2012 o grupo estreia o espetáculo Jacy, com o qual inciou suas pesquisas estéticas de teatro documental. Com este espetáculo entrou na lista dos 10 melhores espetáculo do ano pelo jornal Estado de São Paulo. Em 2015 estrearam um espetáculo baseado na obra de Marguerite Duras, denominado Por Que Paris? Em 2017, com 10 anos de existência, o grupo apresentou o trabalho - $A$ Invenção do Nordeste. Em 2019, A Invenção do Nordeste ganhou o Prêmio Cesgranrio de Melhor Espetáculo; Prêmio Shell de Melhor Dramaturgia; Prêmio Botequim Cultural de Melhor Autor; Prêmio do Humor de Melhor Dramaturgia, Direção e Espetáculo e o Prêmio APTR - Associação dos Produtores de Teatro do Rio de Janeiro, nas categorias "Autor" e "Ator Coadjuvante"3.

Figura 2 - Quitéria Kelly e Cleilson Queiroz Lopes durante a entrevista online

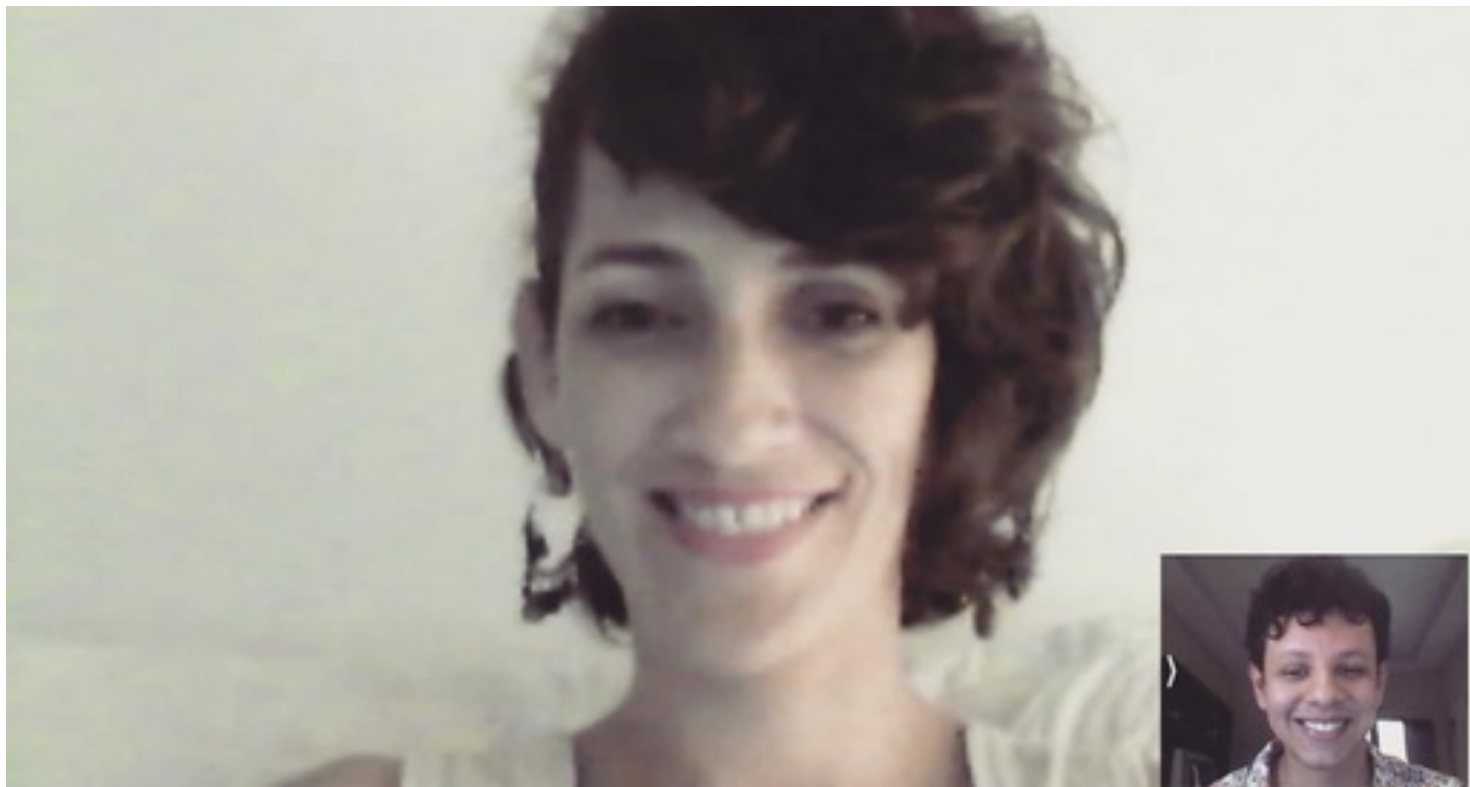

Dados elaborados em dialogo com os sites: https://www.sympla.com.br/teatrocarmin e http://www.grupocarmin.com 
Quitéria, primeiramente obrigado pela disponibilidade. Nos conhecemos na oficina de teatro documentário no Sesc Copacabana e logo em seguida eu escrevi uma crítica sobre o espetáculo $A$ Invenção do Nordeste. Hoje você me disponibiliza esta entrevista que é muito importante para continuar pensando o teatro documentário. Minha primeira pergunta é a seguinte: na abertura do site do grupo Carmin", existe a seguinte afirmação, "grupo de teatro de Natal - RN, que trabalha com teatro, memória e história através dos documentos de vida." Gostaria que você me falasse como se dá esta relação no grupo.

Trabalhar com o material vivo: o documento que também é corpo e memória, foi descoberto no processo de montagem da peça Pobres de Marrés, que era um processo em que íamos para a rua onde observávamos os corpos e trazíamos os desenhos destes como inspiração para a sala de ensaio a partir da mímesis corpórea. O Henrique ${ }^{6}$ escrevia a dramaturgia a partir destas observações. Nós nos inspirávamos na mímesis corpórea, mas não a reproduzíamos. Nós partíamos da rua para criar novos corpos, falas e histórias. A partir deste trabalho, descobrimos o potencial que a rua tinha e o potencial das micro histórias e das histórias privadas que podem ter um potencial enorme, podendo tomar inclusive a dimensão de macro história. Nós falávamos de duas moradoras de rua, selecionando o campo feminino da rua, pois descobrimos que é bem diferente o universo feminino do masculino na rua.

Descobrimos uma ética da rua interessantíssima, eles se protegem. O grupo de moradores de rua que nós pesquisamos não roubam e não pedem esmola. Descobrimos também o potencial que estas histórias tinham para falar de políticas, partindo da história de duas moradoras de rua que cercavam o teatro onde a gente ensaiava. Descobrimos que não existem políticas públicas para moradores de rua, para mulheres de rua, mulheres inclusive que são estupradas

${ }^{4}$ Link do site: http://www.grupocarmin.com/

Espetáculo que estreou em 2007 em Natal (RN). Sinopse: Duas moradoras de rua acham um jornal no lixo com uma promessa. A partir daí começa a espera. Este é o ponto de partida da peça "Pobres de Marré", do Grupo Carmin. Ficha Técnica: Duração: 50 min; Faixa etária: 10 anos; Atrizes: Quitéria Kelly e Alessandra Augusta; Texto e Direção: Henrique Fontes; Cenografia: Matyeu Duvignaud; Iluminação: Anderson Rodrigo; Figurino: O Grupo; Maquiagem: Bruno Finizolla.

${ }^{6}$ Henrique Fontes é o diretor e o dramaturgo de Pobres de Marré. 
na rua. Não existem abrigos públicos que acolham estas pessoas. Então nós fomos descobrindo que a partir de histórias pequenas nós poderíamos falar de questões maiores. Em um certo momento a gente vai descobrir a história e os livros, parando um pouco o trabalho de sala de ensaio para ler. Descobrimos na literatura, história e geografia, conceitos que davam suporte para o que estávamos escrevendo em cena. Foi quando entraram os dados documentais e a potência que isto tem, uma vez que quando falamos de uma moradora de rua, ou de Jacy por exemplo, são personagens distantes da plateia, mas quando colocamos dados históricos, datas e lugares, conseguimos situar a plateia, aproximando-a. É um convite para que estas pessoas façam parte da narrativa com a gente. Quando eu falo “em 1992 Jacy estava..." imediatamente parte da plateia vai se perguntar onde estava em 1992. A plateia se insere na história também e vai se localizando na história, na linha narrativa da história de Jacy.

Nós ainda estamos descobrindo estes potenciais, mas ainda temos muito o que estudar porque o teatro documentário ainda é muito novo no Brasil. Nós temos pouca escrita sobre isso. Para que estudássemos este tema era muito difícil, pois tínhamos que buscar material da américa latina. Trabalhos como de Lola Arias $^{8}$ e de alguns europeus também. Sabemos que já existe teatro documentário no Brasil, mas existe pouca escrita. Nós fomos descobrindo o potencial dos elementos jornalísticos na prática. Estes elementos tinham um impacto na plateia que nós não lemos em lugar nenhum, mas descobrimos experimentando na cena.

\footnotetext{
7 Primeira peça de teatro documentário do grupo. Ficha técnica = Dramaturgia: Henrique Fontes e Pablo Capistrano; Direção: Henrique Fontes; Atores: Quitéria Kelly, Mateus Cardoso, Robson Medeiros e Henrique Fontes. Estreia em 2013 em Natal. Sinopse: A peça "Jacy" marca a entrada do grupo Carmin na pesquisa do Teatro Documental. Ela conta a história real de Jacy, uma mulher nascida em 1920 e cujos pertences foram encontrados em 2010, dentro de uma frasqueira, abandonada na Av. Prudente de Morais, em Natal/RN. Ficha Técnica = Textos: Pablo Capistrano e Iracema Macedo; Dramaturgia: Henrique Fontes e Pablo Capistrano; Direção: Henrique Fontes; Assistente de direção: Lenilton Teixeira; Consultoria: Marcio Abreu; Atores: Quitéria Kelly, Mateus Cardoso, Robson Medeiros e Henrique Fontes; Videomaker: Pedro Fiúza; Designer de Luz: Ronaldo Costa; Direção Artística e Cenografia: Mathieu Duvignaud; Trilha sonora original: Luiz Gadelha e Simona Talma; Coordenação de Produção: Quitéria Kelly.

${ }^{8}$ É escritora, diretora de teatro, cinema e performer. Colabora com pessoas de diferentes origens (veteranos de guerra, ex-comunistas, crianças búlgaras etc.) em projetos de teatro, literatura, música, cinema e artes visuais. Suas obras atravessam a fronteira entre ficção e realidade.
} 


\section{Dentro do contexto do teatro nordestino, vocês encontram grupos que trabalham com teatro documentário?}

Acho que não. Porém, nós encontramos grupos que trazem linguagens que nos interessam. Na montagem de Jacy, que foi quando nós descobrimos esta linguagem, assistimos e lemos bastante coisa de Lola Airas. Mas a estética do Carmin foi uma descoberta de sala de ensaio. Temos como referência grupos que gostamos muito como Magiluth ${ }^{9}$ o Bagaceira ${ }^{10}$ do Ceará, O Máquina11, que são grupos que quebram um pouco com a estética regionalista que sempre foi um problema para o Carmin, pois nós não éramos regionalistas e não gostaríamos de fazer isto, embora tenhamos sido criados no Nordeste. O Marcelo Soler ${ }^{12}$ de São Paulo também foi uma grande referência. Pode ser que alguns grupos fizessem teatro documentário, mas nós não conhecíamos.

Na peça $A$ invenção do Nordeste ${ }^{13}$, o grupo aborda questões de identidade, apontando que ser nordestino não cabe num conjunto de características fechado, que a vida em si é uma ficção e a identidade é plural. Como estas temáticas foram discutidas para a montagem da peça?

Foi e continua sendo uma pesquisa muito grande. Eu estou terminando de

${ }^{9}$ Grupo de teatro dinamarquês. Link do site: https://www.grupomagiluth.com.br/

${ }^{10}$ Grupo de teatro cearense. Link do site: https://bagaceiraoficinas.wordpress.com/

${ }^{11}$ Grupo de teatro cearense. Link do site: http://teatromaquina.weebly.com/

12 Diretor, pedagogo do teatro e arte-educador. Mestre e Doutor em artes Cênicas pela ECA/USP. Membro fundador da Cia. Teatro Documentário. Professor de teatro da ECA/USP.

13 Segunda peça de teatro documentário do Grupo Carmin, com estreia no ano de 2017 em Natal. Sinopse: Motivada por uma série de reações xenófobas contra os nordestinos, durante as eleições presidenciais de 2014, a atriz Quitéria Kelly do Grupo Carmin entrou em contato com a obra do Professor Dr. Durval Muniz de Albuquerque Jr, que escreveu o livro: "A Invenção do Nordeste e Outras Artes". Quitéria então compartilhou com os demais integrantes do grupo, o seu desejo de criar uma peça que contribuísse para a desconstrução da imagem estereotipada do Nordeste e do(a) nordestino(a). Seria seu primeiro trabalho como diretora. Ficha Técnica = Quitéria Kelly: Direção e figurino; Pedro Fiuza: Assistência de direção, dramaturgia audiovisual e desenho de luz; Durval Muniz Jr: Consultoria intelectual; Mathieu Duvignaud: Direção de arte e cenografia; Henrique Fontes e Pablo Capistrano: Dramaturgia; Henrique Fontes, Mateus Cardoso e Robson Medeiros: Elenco; Ana Claudia Albano Viana: Preparação corporal; Gilmar Bedaque: Preparação vocal; Mariana Hardi: Produção executiva; Gabriel Souto: Trilha original; Anderson Galdino: Assistência Técnica; Juliano Barreto: Editor de vídeo; Deus e o Diabo na Terra do Sol de Glauber Rocha: Imagens de apoio - Todos os direitos reservados - Copyrights Consultoria LTDA. 
ler um livro que não consegui terminar quando estava montando $A$ Invenção do Nordeste, que é A ralé brasileira de Jessé Souza e ele fala muito sobre identidade neste livro. A identidade brasileira, o jeitinho brasileiro e onde surgiu, as suas raízes. Na pesquisa da peça $A$ invenção do Nordeste, nós partimos do livro do historiador Durval Muniz, onde o autor desconstrói a ideia de identidade nordestina. Como você poderia ter uma identidade quando se é múltiplo? São nove estados que formam o Nordeste de características completamente diferentes. Isto se dificulta ainda mais quando estamos falando de teatro nordestino. Devemos nos perguntar: teatro nordestino a partir de onde? Do Maranhão? Da Bahia? É difícil assim como falar sobre teatro brasileiro, porque a gente não pode resumir isto numa única coisa, porque o teatro brasileiro não é possível de ser resumido. Nós não nos encaixávamos nesta tentativa de resumir o Nordeste. Nós começamos a perceber estas questões quando começamos a viajar com a peça Jacy e os festivais nos colocavam na cota de teatro nordestino. Quando as pessoas iam assistir à peça, elas chegavam para a gente dizendo que não parecia teatro nordestino. Nós então perguntávamos: mas então o que é teatro nordestino? O que é que se esperava da gente? O que se esperava era a estética da fome, a estética da miséria, que sempre foi associada à toda a arte que foi produzida no Nordeste durante muito tempo. A seca, os tons ocres, os instrumentos, a chita, a terra, o chão rachado, a narrativa baseada no cordel e na xilogravura. Quando você foge disto, parece que está traindo a sua identidade. Uma identidade que foi impregnada e compensada em você. Durval Muniz fala que em 1922 houve um congresso regionalista em que intelectuais como Gilberto Freire e outros pensadores de Pernambuco, do Maranhão e da Bahia se reuniram em Olinda para definir o que seria a identidade nordestina, ou seja, é algo pensado e planejado. Eles pensaram no gibão, no chapéu do cangaceiro.

Neste exato momento eu estou numa crise com o cangaço. Nós defendemos muito o cangaceiro, mas foi horrível o cangaço. Os cangaceiros pegavam meninas de onze anos, estupravam e sequestravam estas meninas. Isto foi o cangaço. Matavam, roubavam, e é este modelo de cangaço que hoje é reproduzido no Brasil. E nós vamos ter orgulho disto? O cangaço, foi romantizado pela literatura e pelas 
artes plásticas, houve uma romantização do cangaço. Quando falamos que temos sangue de cangaceiro nas veias, temos que lembrar que este sangue é de assassino e estuprador. Tem toda a questão de que lampião ajudava os pobres, mas a gente tem que mudar o discurso de quem dá esmola é o bom-feitor. Hoje a gente tem a mesma coisa só que com cabeças diferentes, os coronéis mudaram. São vereadores e deputados que dão prótese dentária ou uma caixa d'água e isto é a mesma coisa.

Esta questão de identidade reverbera muito forte no grupo porque nós nascemos em Natal, uma Natal urbana ouvindo Rock em um bairro boêmio, assistindo filmes da Europa do Leste, então a gente se distanciava da ideia de ser nordestino, ao mesmo tempo em que não poderíamos negar como foi e é importante a nossa cultura. Ela nos diferencia de outras regiões e faz com que o Brasil seja múltiplo culturalmente, mas o problema é quando ela nos aprisiona. Um exemplo é um ator nordestino não poder fazer um carioca na novela das oito. A grande questão para o grupo era: como o estereótipo reduz a complexidade do ser-humano. Quando você fala nordestino, imbuído na palavra, tem uma série de imagens que foram associadas a ela, que não tem como você fugir: burro, desinformado, parado no tempo, feio. Este é o perigo e a ideia é desconstruir isto, a ideia é que nossa geração construa uma nova narrativa para o Nordeste, que extrapole estes estereótipos. A gente construiu Jacy como nosso jeito natalense. É contemporâneo, tem projeção, documentos, tons de cinza e preto, é escuro, mas é natalense. Sempre vai carregar isto.

\section{Você é atriz na peça Jacy, mas assume o papel de diretora na peça $A$} invenção do Nordeste. Como acontece a dinâmica das funções no grupo?

A gente trabalha como circo. Nós praticamente moramos juntos. É uma filosofia de grupo nós formarmos os nossos integrantes. Pelo desejo de uma formação em que todos os integrantes passem pelo máximo de funções possíveis que um grupo possibilita e também pela questão financeira, pois ainda não temos uma estrutura que nos permita uma pessoa para cada função. 
Eu faço produção, venda, direção, atuação, ministro oficinas e todo mundo faz um pouco de tudo. A peça $A$ invenção do Nordeste é minha primeira direção. Eu sempre fui dirigida por Henrique Fontes. Eu sou a fundadora do grupo, mas sempre fui dirigida, muito por uma questão de autoestima, eu não me sentia preparada para assumir uma direção embora eu interferisse muito na direção do Henrique. O grande trunfo de Jacyfoi uma briga terrível que eu e Henrique tivemos na montagem. A primeira cena dos idosos já estava completamente montada e já tinha meia-hora. Nós já tínhamos texto e cena prontos, mas eu sentia que não tinha passado por processo de criação. Foi então que um dia em um ensaio eu assumi que não queria mais fazer aquele texto, porque nós íamos até o final representando os personagens e eu achava aquilo cansativo. Depois de algumas discussões, eu resolvi trazer referências do professor Marcos Bulhões ${ }^{14}$. Eu peguei um caderno de todas as anotações da aula do Bulhões e levei para o outro dia de ensaio. Nós focamos no termo intertextualidade, que é o ato de juntar textos sem uma relação primeira, na tentativa de criar um único texto. No caso dos dois atores em cena, o espectador pode acompanhar a minha narrativa, a narrativa dele e uma narrativa geral. É um quebra-cabeças montar isso, mas ao mesmo tempo é um jogo maravilhoso. O Henrique então aceitou a proposta. No outro dia trouxe o texto editado e com mais jogo a partir da intertextualidade. A peça foi criando esta dinâmica. Na própria peça a gente conta isso. Nós representamos como seria e depois rompemos a cena narrando. Nós, pensando no lugar do documental, nos preocupamos em narrar como foi o encontro com esta frasqueira. Percebemos na narrativa de Jacy, que quando contávamos para os amigos como achamos a frasqueira, eles tinham muito mais interesse e curiosidade do que saber a história que iríamos contar a partir dela. Ou seja, tinha um potencial muito forte a narrativa do encontro com ela, o real, muito mais que a ficção que nós estávamos a fim de montar.

Foi então que eu fui me sentindo confiante e um pouco cansada de estar em cena em todas as peças do Carmin. Quando eu propus a montagem da peça $A$

${ }^{14}$ Prof. Dr. do Departamento de Artes Cênicas, da Universidade de São Paulo. Diretor, ator, e pesquisador de Teatro e Performance, estuda abordagens de criação e aprendizagem da cena contemporânea. 
invenção do Nordeste, falei que não gostaria de estar em cena, mas que gostaria de experimentar a direção. Claro que Henrique me deu muito suporte por ser a minha primeira experiência. A mesma coisa vai acontecer agora com o Pedro Fiuza $^{15}$. Nós estamos começando a montagem da peça nova e ele vai dirigir. Eu vou voltar para a cena, o Henrique vai escrever e tem os dois outros atores que vão estar em cena comigo.

\section{Vocês utilizam nas duas encenações (Jacy e $A$ invenção do Nordeste) documentos de variadas formas: lidos, projetados, citados na dramaturgia ou mesmo documentos que impulsionam a cena. Como é lidar com estas possibilidades de utilização dos documentos?}

Partindo da frasqueira ${ }^{16}$ da peça Jacy, que foi um elemento muito forte, este documento do real trazia uma potência para a história que estávamos contando. Quando aparece a frasqueira em cena, as pessoas percebem que nós não estávamos inventando, que a coisa está ali. O jornalismo faz o contrário disso, pois ele pega o elemento da ficção e coloca na realidade. Um exemplo pode ser a matéria de uma menina que foi atropelada, então o pai aparece chorando e é colocada uma trilha sonora, que é um elemento cênico. Coloca-se também um filtro preto e branco para narrar a menina saindo de casa. O que a gente faz é o contrário, pois pegamos o elemento do real, o jornalístico, o documento, a memória, o corpo e levamos para a cena como prova de que aquilo realmente aconteceu. Partindo disso, fomos descobrindo que os documentos poderiam ser muitas coisas, inclusive a própria história enquanto livro narrado é uma ficção. Cada um de nós vai ver com os mesmos olhos um mesmo horizonte e vai encontrar coisas diferentes. Este é o grande potencial do elemento documento.

Em A Invenção do Nordeste, nós fomos descobrindo outros elementos que podem servir como documento também, porque parece que as possibilidades vão

${ }^{15}$ Ator e integrante do Grupo Carmin.

${ }^{16} \mathrm{~A}$ frasqueira é o elemento disparador da peça Jacy. Dentro da mesma, existiam diversos tipos de documentos, receitas de remédios e fotografias. A frasqueira tornou-se também um próprio documento e objeto cênico. 
se abrindo e porque a nossa realidade hoje está tão surreal, tão absurda, que qualquer coisa que se coloque em cena hoje, qualquer informação saída do jornal e colocada em cena parece exagero.

Hoje para quem faz teatro documentário, o exercício é bem maior. A pergunta agora é: como trazer algo de real para a cena se o mundo está tão surreal? Então a tentativa é de tentar furar a bolha do lado contrário e esta função é bem difícil. Ontem aconteceu o crime ambiental de Brumadinho e o nosso atual presidente não está preparado nem para falar de casos como estes, então que representação estamos tendo se não temos um chefe de Estado? É assustador. Como cidadã, eu me sinto abandonada. Não tem ninguém que fale por mim. Os bombeiros que estão lá trabalhando e salvando vidas falam melhor que o nosso presidente. Então como fazer teatro documentário num país como o nosso é uma pergunta que eu me faço. A nossa próxima peça é inspirada na obra do Jessé Souza ${ }^{17}$ e nós vamos contar a história do surgimento da classe média no Brasil. Estamos estudando muito isto. Eu estava escrevendo um pouco e aqui do lado, no condomínio, tem uma piscina e tinham umas peruas classe média conversando. O discurso era muito surreal. Elas falavam de empregadas domésticas que não querem mais dormir em casa e que era difícil conseguir pagar os direitos das empregadas. Eu reflito muito sobre o trabalho a partir destas cenas cotidianas.

No espetáculo $A$ invenção do Nordeste, vocês utilizam características autobiográficas e documentais em diálogo com as novas tecnologias: câmera, projetor, dentre outros. Como foi trabalhar com a temática da xenofobia, utilizando-se de uma estética alternativa como o teatro documentário no contexto nordestino?

Trabalhar com a xenofobia não foi muito difícil porque a gente sofre isto no dia-a-dia. A autobiografia partiu muito disto. Eu fiz um exercício com os meninos para pegar elementos das histórias pessoais, tendo em vista que eles fazem testes

17 Jessé José Freire de Souza é um sociólogo natural de Natal (RN), professor universitário e pesquisador brasileiro que atua nas áreas de Teoria Social, pensamento social brasileiro e estudos teórico/empíricos sobre desigualdade e classes sociais no Brasil contemporâneo. É autor dos livros A Ralé Brasileira, A Radiografia do Golpe, A Elite do Atraso e A Classe Média no Espelho. 
e a gente tentava escrever isto, colocar numa escrita. Os depoimentos foram diversos e a temática de xenofobia sempre aparecia.

O fato de termos viajado pelo Brasil com a peça Jacye as pessoas sempre nos receberem com certo desdém por sermos de Natal, como uma cota. Nós pegamos elementos muito fortes dos atores. A intenção era que o Mateus fosse realmente o Mateus e Robson realmente o Robson ${ }^{18}$. As características dos atores ficam: Robson é do interior do Rio Grande do Norte, sertanejo e Mateus é um menino de Natal, classe média, mas criado numa família evangélica e filho de um pastor. Estes elementos deles eram muito ricos para a trama que gostaríamos de criar. Já existia uma disputa muito legal de dois nordestinos vivendo uma realidade completamente diferente. Só aqui nós já tínhamos dois nordestes diferentes, então não dava para sermos reducionistas dizendo que somos um só.

Não sei se ficou muito claro porque eu não gostaria de deixar isto muito delineado, mas alguns depoimentos dos atores que são reais, a gente utiliza a câmera ou a imagem, porque dá uma densidade jornalística para a cena. Tem um momento em que eles falam dos pais deles, que não fica claro que são os pais. É o momento em que a peça fala sobre o que é ser cabra macho. Esta cena partiu de um exercício em que eu pedi para os atores para que eles me trouxessem a relação deles com os pais. Foram dois ensaios bem difíceis, eles choraram muito porque um é gay e o pai é pastor, o outro tem um pai alcoólatra que mora no sertão. Nós sempre temos coisas muito delicadas e íntimas. E quando se abre isto, você expõe o ator ao mesmo tempo em que dilata ele no palco. São cenas ainda hoje muito difíceis para os atores. Trabalhar com o material autobiográfico usando isto como potência documental e reforçada pelos elementos de audiovisual. Todos estes elementos vêm para reforçar ou suavizar coisas, então a gente vai dosando.

Outra coisa que nós tivemos cuidado em $A$ invenção do Nordeste, foi não usar muito o audiovisual, para não ficar disputando cena com a gente e eu acho que na próxima peça nós vamos tirar mais ainda, porque desde $A$ Invenção do Nordeste, o nosso desejo é o de voltar para o ator, voltar para a experiência do

${ }^{18}$ Integrantes e atores do Grupo Carmin. 
ator em cena e que estes elementos do real criem uma potência aqui, eu e você e que as projeções sejam utilizadas com menor frequência, pois percebemos que as relações se desconectam às vezes. A construção da dramaturgia colocando elementos audiovisuais, documentais e ficcionais é um quebra-cabeças. Como fazer com que cada um destes elementos não sobreponha os demais é um desafio.

No trabalho de vocês, existe uma relação com a ampliação da imagem captada ao vivo e também com a justaposição de imagens. $O$ ator ao vivo/projetado, o ator sem mediação das tecnologias ou mesmo mediado. Eu gostaria de saber o que vocês querem comunicar com estes efeitos. Há diferença entre eles?

Em Jacy, a gente brincou muito com a projeção porque tinha um cineasta em cena, que é o Pedro Fiuza e ele trazia muitas referências cinematográficas para o grupo. Há um momento em que eu me coloco na frente de uma foto clássica do marinheiro beijando a enfermeira na segunda guerra mundial e no ensaio eu fiquei na frente da enfermeira imitando ela. O Pedro então gostou da imagem e quis brincar com esta leitura de Jacy se colocando na frente desta imagem.

A gente foi descobrindo que existe uma potência poética também nestas imagens e que você pode brincar com a sombra, por exemplo. Tem um momento que até ganhou um elogio no Estadão, onde o crítico comentou que era a cena mais bonita que ele já tinha visto no teatro, o momento em que Jacy vai morrendo e eu fico na frente do painel, vou envelhecendo e o Henrique vai fazendo uma linha com a minha sombra. Aquela cena não foi praticamente nada, ela partiu de uma brincadeira e a gente foi descobrindo ali uma potência poética, pois é quando o audiovisual se transforma em poesia. Para além da tentativa de reforçar a imagem ou mesmo o real e trazer o político para a cena, existe também a potência poética que estes elementos trazem. Esta por exemplo é uma imagem apenas poética, que vai mostrando o envelhecimento dela numa brincadeira de projeção e sombra, onde a morte é o momento em que a luz apaga no final.

A gente buscava a possibilidade de delicadeza nestes elementos que são 
brutos como o projetor e a câmera. Fomos encontrando a mão do artista, do artesão que consegue brincar com a cena. Trata-se de um cuidado ao manipular a sombra, a luz. Gostamos de fazer isto porque o teatro que praticamos é muito artesanal e nós poderíamos substituir as imagens, colocar tudo na memória de um computador e só dar play, mas não. Nós pegamos o celular, colocamos a frasqueira embaixo e o celular filma a frasqueira que projeta a imagem. Isto é artesanal e esta pobreza cria uma estética que é simples e as vezes consegue chegar muito mais do que dez projetores.

É possível ir na precariedade criando poesia, criando delicadeza. O exercício de Marcos Bulhões que foi o início para a construção de Jacy, logo depois foi redescoberto a partir de imagens, pois muitas vezes não precisamos nem falar. Às vezes é possível substituir um trecho inteiro de um texto apenas com uma imagem. É difícil, é um quebra-cabeça, mas é um jogo do artista. É trabalho de um artista transformar um trecho filosófico em imagem. Nossa última cena de Jacy é baseada no anjo da história de Walter Benjamin, onde pegamos tudo o que já escrevemos de texto, colocamos os textos no meio da cena e ligamos cinco ventiladores dispostos em cada extremidade do palco. Então transformamos o trecho do texto de Walter Benjamin em que ele fala que a história nada mais é que um amontoado de fragmentos em que vemos na nossa frente o passado e o futuro que está atrás a gente não vê. Nós somos levados para trás e tudo o que a gente vive vai se bagunçando na frente como um furacão. Nós tivemos um pouco de trabalho, mas conseguimos quebrar este trecho filosófico em uma imagem.

Eu acho que é preciso ser generoso com os elementos porque as vezes a gente quer falar muito, mas é preciso ter calma porque tudo tem seu tempo. Em A invenção do Nordeste tinha muita coisa para ser falada, o feminino não entrou, mas a gente precisava escolher qual era a nossa narrativa e o que era mais importante dentro de uma tese de doutorado que é ampla, pois são mais de cinco anos de estudo e a gente precisava encontrar o que sintetizava e era mais importante para a gente que servisse para desconstruir o estereótipo do nordestino. Então tivemos que optar por escolhas cruéis para criar uma narrativa, mas poderíamos ter feito três outras peças com a tese do Durval Muniz. 
No site de vocês, alguns integrantes são chamados de ator-técnico. Nos espetáculos $A$ invenção do Nordeste e Jacy, os atores são também técnicos dos dispositivos tecnológicos. O que você pensa desta relação do ator com os dispositivos tecnológicos?

Seria muito fácil a gente contratar um técnico mesmo, mas quando se coloca um ator que também é poeta e autor da história, é muito diferente porque ele vai fazer um tipo de edição que é diferente. Em Jacy, quem está fazendo agora é o Mateus. O Mateus tem uma forma de filmar muito diferente do Pedro Fiuza porque ele olha para o mesmo horizonte com olhos diferentes. A narrativa vai ser construída de uma forma diferente para ele. Quando eu estou de frente para ele, o mesmo filma minha boca, meu olho. Mas ao mesmo tempo ele tem que ser técnico por que é um objeto, um aparelho que ele tem que saber manipular. Se acontecer algum problema, ele terá que resolver, então vai para além da questão do artístico.

No Carmin todos somos um pouco técnicos. Eu monto luz, manipulo o som. Todos nós somos técnicos da nossa obra. O artístico vem também do cuidado com o material que nós estamos editando na hora. As duas últimas peças são espetáculos praticamente editados ao vivo. Nós temos uma cena pré-gravado em A invenção do Nordeste que aborda as questões do Renan Calheiros. Fora esta cena, todas as outras são cenas editadas ao vivo. Nós precisamos de artistas com sensibilidade poética para editar e filmar na hora.

A técnica por meio dos dispositivos tecnológicos dá ao ator o potencial de poder mudar a narrativa. Jacy é uma peça que nós estamos atualizando o tempo todo. Nós colocamos recentemente em um trecho no qual falamos "na época da ditadura militar, as pessoas que abriam a boca eram inseridas na lista de personas non gratas". O Henrique fala isto, mas não tinha nenhuma imagem. Nós estreamos em São Paulo no dia em que Teori Zavascki19 ${ }^{19}$ morreu. O helicóptero dele caiu no

19 Teori Albino Zavascki (Faxinal dos Guedes, 15 de agosto de 1948 - Paraty, 19 de janeiro de 2017) foi um jurista, professor e magistrado brasileiro. Foi ministro do Superior Tribunal de Justiça (STJ) e do Supremo Tribunal Federal (STF). Ganhou expressiva notoriedade após tornar-se o ministro relator da Operação Lava Jato no STF, analisando os casos de pessoas com foro privilegiado, homologando delações premiadas e acordos de leniência. 
Rio de Janeiro e ninguém sabe como. Ele morreu misteriosamente na semana em que iria denunciar 156 deputados, e mais outros vários políticos. Neste trecho de Jacy, Pedro enquanto técnico e diretor de audiovisual, pediu para colocar uma imagem de Teori Zavascki no trecho em que a fala é dita. Esta imagem entrou e saiu muito rapidamente e a plateia ficou perplexa. É real porque atualizou o nosso tempo. É uma sacada técnica, que acaba sendo poético e político também. Na mesma cena estamos acrescentando Marielle Franco ${ }^{20}$, então a cena passa a imagem de Teori Zavascki, Marielle e de quem mais for desaparecendo porque as pessoas estão morrendo. O texto ganha uma potência muito maior porque aconteceu lá atrás, está acontecendo agora e eu não estou me dando conta.

Isto tudo para dizer que Pedro não é ator, mas um técnico que manipula elementos técnicos como câmera, fio, projeção com a potência poética de um artista. Nós preparamos os atores para que os mesmos manipulem os elementos sem perder a poesia.

\footnotetext{
20 Marielle Francisco da Silva, conhecida como Marielle Franco (Rio de Janeiro, 27 de julho de $\underline{1979}$ - $\underline{\text { Rio de }}$ Janeiro, 14 de março de 2018), foi uma socióloga e política brasileira. Filiada ao Partido Socialismo e Liberdade (PSOL), elegeu-se vereadora do Rio de Janeiro para a Legislatura 2017-2020, durante a eleição municipal de 2016, com a quinta maior votação. Marielle defendia o feminismo, os direitos humanos, e criticava a intervenção federal no Rio de Janeiro e a Polícia Militar, tendo denunciado vários casos de abuso de autoridade por parte de policiais contra moradores de comunidades carentes. Em 14 de março de 2018, foi

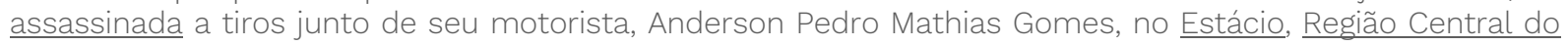
Rio de Janeiro.
} 
Fotografia: Vladimir Alexandre

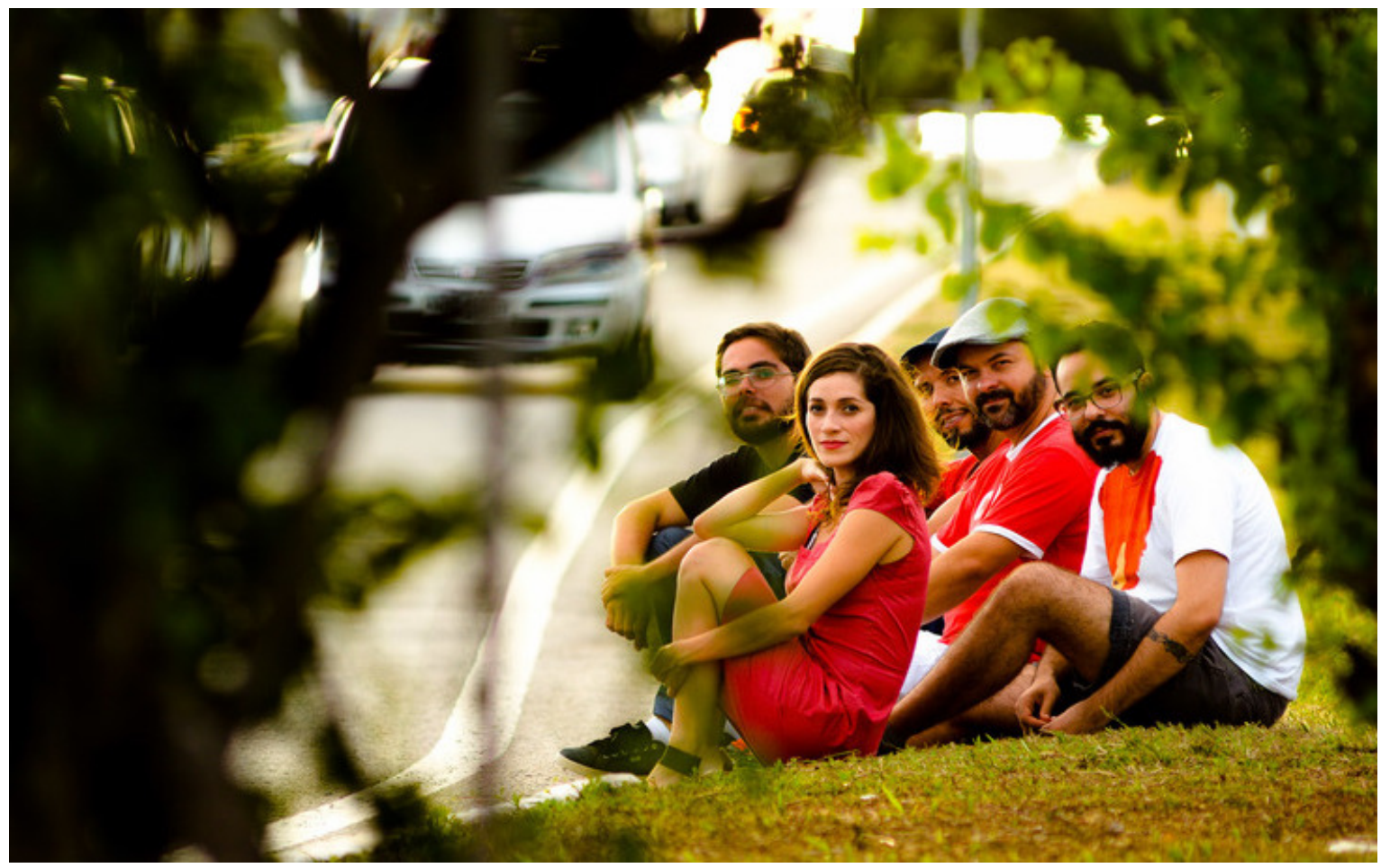

Fonte: http://www.grupocarmin.com/historia

Recebido em: 25/02/2020

Aprovado em: 26/03/2020

Universidade do Estado de Santa Catarina - UDESC

Programa de Pós-Graduação em Teatro - PPGT Centro de Arte - CEART Urdimento - Revista de Estudos em Artes Cênicas urdimento.ceart@udesc.br 